\title{
Electrical Properties of Junctions between Electrodeposited Magnesium Phthalocyanine and Aluminum
}

\author{
Teruhisa Kudo, Mutsumi Kimura, Kenji Hanabusa, \\ and Hirofusa SHIRAI ${ }^{\dagger}$ \\ Department of Functional Polymer Science, Faculty of Textile Science and Technology, \\ Shinshu University, Ueda, Nagano 386, Japan
}

(Received May 12, 1997)

\begin{abstract}
Tetracarboxyphthalocyaninatomagnesium(II) $[\mathrm{Mg}(\mathrm{II})$-taPc $]$ films were obtained on indium/tin oxide (ITO) coated glass electrodes by electrodeposition, using $\mathrm{MgCl}_{2}, \mathrm{CaCl}_{2}, \mathrm{CoCl}_{2}$, or $\mathrm{ZnCl}_{2}$ as a supporting electrolyte. The electrical properties of junctions between electrodeposited $\mathrm{Mg}(\mathrm{II})$-taPc film and aluminum electrode were evaluated by current-voltage measurements. The diode based on $\mathrm{Mg}(\mathrm{II})-\mathrm{taPc}$ film containing $\mathrm{Mg}^{2+}$ as a bridging metal ion exhibited Zener-type breakdown, while the diode based on $\mathrm{Mg}(\mathrm{II})-\mathrm{taPc}$ film containing $\mathrm{Ca}^{2+}$ or $\mathrm{Zn}^{2+}$ as a bridging metal ion showed almost symmetrical $\mathrm{I}-\mathrm{V}$. The diode based on $\mathrm{Mg}(\mathrm{II})$ - taPc film containing $\mathrm{Co}^{2+}$ as a bridging metal ion was electrically unstable. The diode based on $\mathrm{Mg}(\mathrm{II})$-taPc film containing $\mathrm{Mg}^{2+}, \mathrm{Ca}^{2+}$, or $\mathrm{Zn}^{2+}$ as a bridging metal ion exhibited a photocurrent on forward biased condition.

KEY WORDS Tetracarboxyphthalocyaninatomagnesium / Electrodeposition / Schottky Diodes /

Zener-Type Breakdown/Photoconduction/
\end{abstract}

Metallophthalocyanines (Mt-Pc) attract considerable interest because of their high electrical conductivity, ${ }^{1,2}$ optical sensing properties, ${ }^{3,4}$ and $p$-type semiconduction. ${ }^{5-8}$ Early research on solar cells having a Pc film has focused on the Schottky junction. ${ }^{9-13}$ However, comparatively little has been done to investigate the fundamental aspects of junction interfaces between the film of phthalocyanine polymer doped with ion and metal electrode.

We reported a method for the preparation of 2,9,16,23tetracarboxyphthalocyaninatocobalt(II) [Co(II)-taPc] films on indium/tin oxide coated (ITO) glass electrodes by electrodeposition. ${ }^{14}$ Recently we found that $\mathrm{Mg}$ (II)taPc electrodeposited films can also be prepared on ITO electrode by similar method for $\mathrm{Co}(\mathrm{II})$-taPc film. In this paper, we will report the fabrication of the Schottky-type diodes based on the junction interface between $\mathrm{Mg}$ (II)taPc film containing bridging metal ions and aluminum electrode. ${ }^{15-17}$

Since $\mathrm{Mg}-\mathrm{Pc}$ shows strong fluorescence when exposed to ultraviolet or visible light, ${ }^{18}$ a device using a $\mathrm{Mg}-\mathrm{Pc}$ film should be highly sensitive to light irradiation. ${ }^{4}$

An ITO electrode is used as material which enables holes to enter semiconductor film, whereas the counter electrode is aluminum which has a low work function and enables electrons to enter the conduction band of Pc. ${ }^{19,20}$

This paper presents the electrical features of the junction interface between $\mathrm{Mg}-\mathrm{Pc}$ film containing bridging metal ions and an aluminum electrode.

\section{EXPERIMENTAL}

\section{Materials}

$\mathrm{Mg}$ (II)-taPc was prepared according to the method for $\mathrm{Co}(\mathrm{II})-\mathrm{taPc}^{21}$ A reaction mixture consisting of $3.00 \mathrm{~g}$ $\left(1.6 \times 10^{-2} \mathrm{~mol}\right)$ of trimellitic anhydride, $0.37 \mathrm{~g}(3.9 \times$

\footnotetext{
${ }^{\dagger}$ To whom correspondence should be addressed.
}

$\left.10^{-3} \mathrm{~mol}\right)$ of magnesium chloride, $10.0 \mathrm{~g}\left(1.7 \times 10^{-1} \mathrm{~mol}\right)$ of urea, and $0.20 \mathrm{~g}\left(1.6 \times 10^{-4} \mathrm{~mol}\right)$ of ammonium molybdate was poured into a separable flask and heated at $200^{\circ} \mathrm{C}$ for $20 \mathrm{~min}$, stirring quickly the mixture. The residue was poured into $500 \mathrm{ml}$ water and the solution was filtered off. After extraction in a Soxhlet for $24 \mathrm{~h}$ with water, the residue was poured into $150 \mathrm{ml} 50 \mathrm{wt} \%$ $\mathrm{KOH}$ aqueous solution and the solution was refluxed at $80^{\circ} \mathrm{C}$ for $24 \mathrm{~h}$. The precipitate was filtered off and extracted with water. A $6 \mathrm{M} \mathrm{HCl}$ aqueous solution was dropped into the alkaline solution until the $\mathrm{pH}$ of the solution changed into 2 , and the resulting precipitate was filtered off. After extraction in a Soxhlet for $24 \mathrm{~h}$ with methanol, the product was dried in vacuo at room temperature: yield $0.42 \mathrm{~g}(16 \%)$; UV-Vis $(N, N$-dimethylformamide, DMF) $\lambda_{\text {max }} 690 \mathrm{~nm}$ (Q-band for Pc); IR $(\mathrm{KBr}) 1698 \mathrm{~cm}^{-1}\left(v_{\mathrm{C}=\mathrm{o}}\right)$. Anal. Calcd for $\mathrm{Mg}$ in $\mathrm{Mg}$ (II)taPc: $\mathrm{Mg}, 3.51 \%$. Found: $\mathrm{Mg}, 3.22 \%$.

DMF was distilled under reduced pressure before use. Supporting electrolytes, acetone, and aluminum were of analytical grade from commercial origin.

\section{Fabrication of Devices Based on Mg(II)-taPc Film Containing Bridging Metal Ions}

$\mathrm{Mg}$ (II)-taPc films containing bridging metal ions on ITO electrodes were prepared by cathodic electrolytic deposition using a Hokuto-Denko HA-501 potentiostat/ galvanostat. A mixture of $\mathrm{Mg}(\mathrm{II})-\operatorname{taPc}\left(3 \times 10^{-4} \mathrm{M}\right)$ and $\mathrm{MgCl}_{2}, \mathrm{CaCl}_{2}, \mathrm{CoCl}_{2}$, or $\mathrm{ZnCl}_{2}\left(1 \times 10^{-3} \mathrm{M}\right)$ as supporting electrolyte in dry DMF was poured into the electrolytic cell containing an ITO working electrode and platinum counter electrode. $\mathrm{Mg}$ (II)-taPc films containing bridging metal ions on the ITO electrodes were prepared by cathodical polarization of the DMF solution containing $\mathrm{Mg}(\mathrm{II})-\mathrm{taPc}$ and a supporting electrolyte with a constant current of $-35 \mu \mathrm{A} \mathrm{cm}^{-2}$ for $30 \mathrm{~min}$. The deposited films were washed with acetone.

Aluminum electrodes were deposited on the $\mathrm{Mg}(\mathrm{II})$ taPc modified ITO electrodes by sublimation at 
$1.3 \times 10^{-3} \mathrm{~Pa}$

\section{MEASUREMENTS}

IR spectrum for $\mathrm{Mg}(\mathrm{II})-\mathrm{taPc}$ was measured with a JASCO FT-IR-7300 Fourier transform infrared Spectrometer using $\mathrm{KBr}$ disk. UV-Vis spectrum for $\mathrm{Mg}(\mathrm{II})-$ taPc was measured with a JASCO UVIDEC-505 UVVis Digital Spectrophotometer. Atomic absorption spectrometry for $\mathrm{Mg}$ in $\mathrm{Mg}(\mathrm{II})-\mathrm{taPc}$ was carried out with a HITACHI 180-50 Atomic Absorption Spectrophotometer. Current-voltage characteristics were measured using an Advantest R8340 Ultra High Resistance Meter. Elemental analyses were carried out with a HORIBA energy-dispersive X-ray microanalyzer, EMAX-5770W. Photoconduction of devices was measured under irradiation of white light from a $300 \mathrm{~W}$ slide projector lamp. Surface structures and thickness of the electrodeposited $\mathrm{Mg}(\mathrm{II})-\mathrm{taPc}$ films containing bridging metal ions were examined with a HITACHI S-2380N scanning electron microscope (SEM).

\section{RESULTS AND DISCUSSION}

Green thin films were obtained on ITO electrodes by constant current electrodeposition from DMF solutions containing $\mathrm{Mg}$ (II)-taPc and $\mathrm{MgCl}_{2}, \mathrm{CaCl}_{2}, \mathrm{CoCl}_{2}$, or $\mathrm{ZnCl}_{2}$ as a supporting electrolyte. When $\mathrm{PbCl}_{2}$ was used as a supporting electrolyte, heterogeneous $\mathrm{Mg}$ (II)-taPc film containing $\mathrm{Pb}^{2+}$ as bridging metal ion was deposited on the ITO electrode. Films failed to form when $\mathrm{FeCl}_{2}$ or $\mathrm{CuCl}_{2}$ was used. These results suggest that the chemical stability of bridging metal ion is an important factor for the electrodeposition of $\mathrm{Mg}$ (II)-taPc film. Since $\mathrm{Mg}^{2+}, \mathrm{Ca}^{2+}$, and $\mathrm{Zn}^{2+}$ have closed shells of electron configurations, these bivalent ions are chemically stable. ${ }^{22,23}$ Since $\mathrm{Fe}^{2+}, \mathrm{Co}^{2+}$, and $\mathrm{Cu}^{2+}$ have electron configurations whose $\mathrm{d}$ orbitals are not filled by electrons and $\mathrm{Pb}^{2+}$ has electron configuration whose $\mathrm{p}$ orbital is not filled by electrons, the valences of these metal ions can be changed. The electron configurations of these metals are listed in Table I.

The chemical structure of $\mathrm{Mg}(\mathrm{II})-\mathrm{taPc}$ film containing bridging metal ions is shown in Figure 1. The monomer of $\mathrm{M}(\mathrm{II})-\mathrm{taPc}$ is polymerized by bridge formation with bivalent metal ion in the electrodeposited M(II)--taPc film. ${ }^{14}$

The Schottky-type diodes were prepared by the formation of aluminum electrode on the $\mathrm{Mg}$ (II)-taPc film containing bridging metal ions. Since Pc derivatives are $p$-type semiconductors, Schottky-type or Mott-type barriers are formed by contact with low work function metal such as aluminum. ${ }^{15}$ Mott-type barriers are likely to be formed because low work function metals are easily oxidized and a resistive thin layer is formed at the junction interface between semiconductor film and metal electrode. The device structure is shown in Figure 2.

The diode based on $\mathrm{Mg}(\mathrm{II})$-taPc film containing $\mathrm{Mg}^{2+}$ as a bridging metal ion exhibited Zener-type breakdown generated by other molecules in the neighborhood of rectifying barriers. This would be due to the existence of bridging metal ions in $\mathrm{Mg}(\mathrm{II})-\mathrm{taPc}$ film. Actually, the existence of bridging metal ions was confirmed for each
Table I. Diode performance

\begin{tabular}{lllc}
\hline $\begin{array}{c}\text { Bridging metal } \\
\text { (Electron } \\
\text { configuration) }\end{array}$ & $\begin{array}{c}\text { Aspect of } \\
\text { film }\end{array}$ & $\begin{array}{c}\mathrm{I}-\mathrm{V} \\
\text { characteristic }\end{array}$ & $\begin{array}{c}\text { Photocurrent } \\
\text { /dark current }\end{array}$ \\
\hline $\begin{array}{l}\mathrm{Mg} \\
\left([\mathrm{Ne}] 3 \mathrm{~s}^{2}\right)\end{array}$ & Homogeneous & Zener-type & 8 \\
$\mathrm{Ca}$ & Homogeneous & Symmetrical & 118 \\
$\left([\mathrm{Ar}] 4 \mathrm{~s}^{2}\right)$ & Not deposit & - & - \\
$\begin{array}{l}\mathrm{Fe} \\
\left([\mathrm{Ar}] 3 \mathrm{~d}^{6} 4 \mathrm{~s}^{2}\right)\end{array}$ & Homogeneous & Unstable & 1 \\
$\mathrm{Co}$ & Not deposit & - & - \\
$\left([\mathrm{Ar}] 3 \mathrm{~d}^{7} 4 \mathrm{~s}^{2}\right)$ & Homogeneous & Symmetrical & 2 \\
$\mathrm{Cu}$ & & & - \\
$\left([\mathrm{Ar}] 3 \mathrm{~d}^{10} 4 \mathrm{~s}\right)$ & $\mathrm{Zn}$ & & - \\
$\left([\mathrm{Ar}] 3 \mathrm{~d}^{10} 4 \mathrm{~s}^{2}\right)$ & Heterogeneous & - & \\
$\mathrm{Pb}$ & & & \\
$\left([\mathrm{Xe}] 4 \mathrm{f}^{14} 5 \mathrm{~d}^{10} 6 \mathrm{~s}^{2} 6 \mathrm{p}^{2}\right)$ & &
\end{tabular}

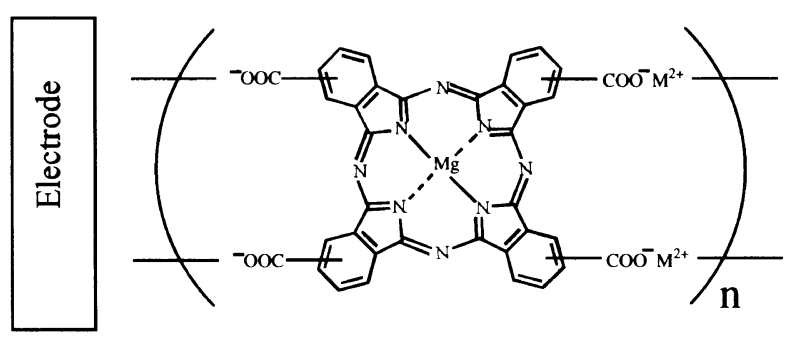

$\mathrm{M}=\mathrm{Mg}, \mathrm{Ca}, \mathrm{Co}$, or $\mathrm{Zn}$

Figure 1. Molecular structure of $\mathrm{Mg}(\mathrm{II})-\mathrm{taPc}$ film containing bridging metal ion.

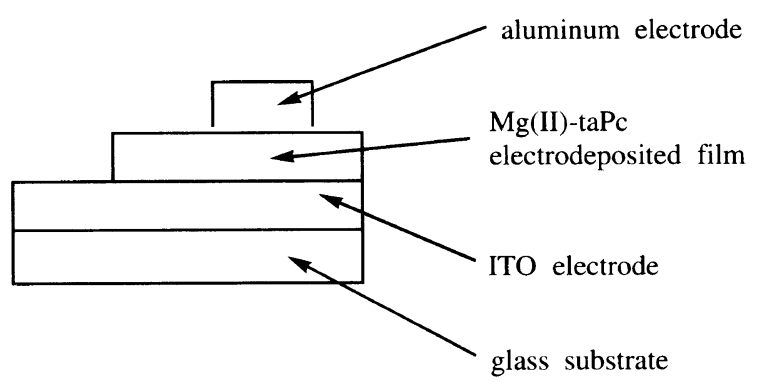

Figure 2. Schematic representation of the diode.

device by X-ray microanalyzer. It seems that the existence of the bridging metals causes the present devices to generate Zener-type breakdown. In fact, many investigators report that devices using the semiconductors with other molecules showed breakdown under the reverse biased condition, ${ }^{20}$ while the devices without other molecules did not. ${ }^{16}$ It is thought that tunneling effect is generated at the interface of the $\mathrm{Mg}(\mathrm{II})-\mathrm{taPc}$ film containing $\mathrm{Mg}^{2+}$ as a bridging metal ion and aluminum electrode under the reverse biased condition because of the decrease of gap between LUMO and HOMO. ${ }^{15,24}$

For previous Schottky-type diodes made by vacuumdeposition of organic semiconductors, high resistance of organic semiconductors decreased electric conductivity. ${ }^{16}$ The high conductivity of the present device is attributed to bridging metal ions in $\mathrm{Mg}(\mathrm{II})-\mathrm{taPc}$ films, since the electrodeposited films with ions have metallic high conductivity. ${ }^{25}$ The dark current-voltage of the diode based on $\mathrm{Mg}(\mathrm{II})$-taPc film containing $\mathrm{Mg}^{2+}$ as 


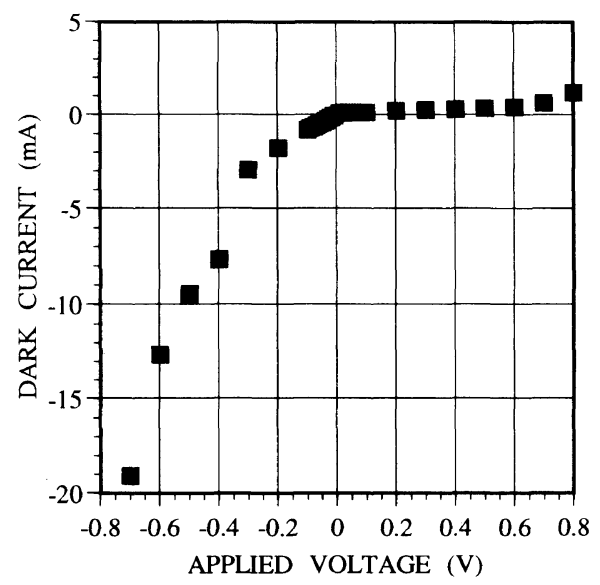

Figure 3. Dark current-voltage characteristic for diode based on $\mathrm{Mg}(\mathrm{II})$-taPc film containing $\mathrm{Mg}^{2+}$ as bridging metal ion.

bridging metal ion is shown in Figure 3.

The low breakdown voltage of the device is due to the great number of bridging metal ions. In conventional Zener-type diodes constructed by an inorganic semiconductors, breakdown voltage is comparatively high since the number of dopants is easily controlled. ${ }^{15}$ However, in the present devices, control of the number of metal ions is difficult because $\mathrm{Mg}$ (II)-taPc films are prepared by bridge formation with metal ions originating from supporting electrolytes in electrodeposition.

$\mathrm{I}-\mathrm{V}$ of the diode based on $\mathrm{Mg}(\mathrm{II})-\mathrm{taPc}$ film containing $\mathrm{Ca}^{2+}$ or $\mathrm{Zn}^{2+}$ as bridging metal ion was almost symmetrical. The magnitude of applied voltage for turn-on of forward biased current was almost equal to that for breakdown of reverse biased current. The electrical properties of the devices of $\mathrm{Mg}(\mathrm{II})$-taPc film containing $\mathrm{Mg}^{2+}, \mathrm{Ca}^{2+}$, or $\mathrm{Zn}^{2+}$ as bridging metal ion were reproducible. The results can be explained by the chemical stability of these metal ions which have closed shells of electron configurations. ${ }^{22,23}$

The diode based on $\mathrm{Mg}(\mathrm{II})-\mathrm{taPc}$ film containing $\mathrm{Co}^{2+}$ as bridging metal ion was electrically unstable. The reproducible values of current of the device were not obtained in any measurement. The electrical unstability is due to the various oxidation states of cobalt ions. ${ }^{22,23}$

The diode based on $\mathrm{Mg}(\mathrm{II})-\mathrm{taPc}$ film containing $\mathrm{Mg}^{2+}, \mathrm{Ca}^{2+}$, or $\mathrm{Zn}^{2+}$ as bridging metal ion exhibited photocurrent under the forward biased condition. The current after light irradiation was larger than that before light irradiation under the forward biased condition. Photocurrent/dark current, the ratio of photocurrent to dark current, of the present devices at applied voltage of $+0.8 \mathrm{~V}$ is summarized in Table $\mathrm{I}$. The diode based on $\mathrm{Mg}(\mathrm{II})-\mathrm{taPc}$ film containing $\mathrm{Ca}^{2+}$ as bridging metal ion showed the largest photocurrent/dark current, which indicates the efficiency of photogeneration of charge carriers. The $\mathrm{Mg}(\mathrm{II})-\mathrm{taPc}$ film containing $\mathrm{Ca}^{2+}$ as bridging metal ion $(350 \mu \mathrm{m})$ was thicker than the film containing $\mathrm{Mg}^{2+}$ or $\mathrm{Zn}^{2+}$ as bridging metal ion (250 $\mu \mathrm{m})$. It is thought that the number of charge carriers in the film containing $\mathrm{Ca}^{2+}$ as bridging metal ion drastically increases by light irradiation because of the large absorbance of this thick film. UV-Vis spectra of $\mathrm{Mg}(\mathrm{II})-$ taPc film containing $\mathrm{Mg}^{2+}$ as bridging metal ion and that of $\mathrm{Mg}(\mathrm{II})-\mathrm{taPc}$ film containing $\mathrm{Ca}^{2+}$ as bridging (a)

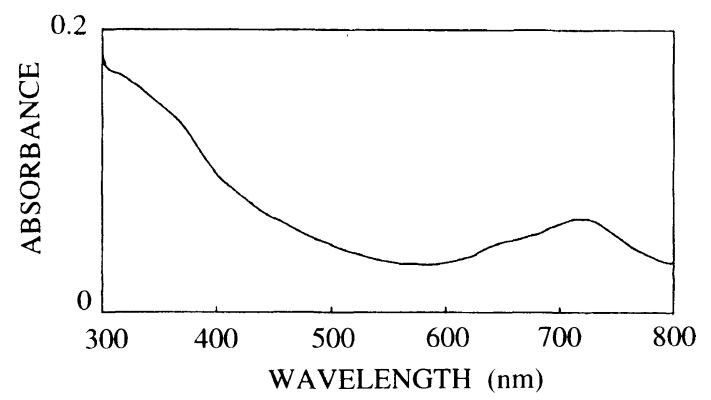

(b)

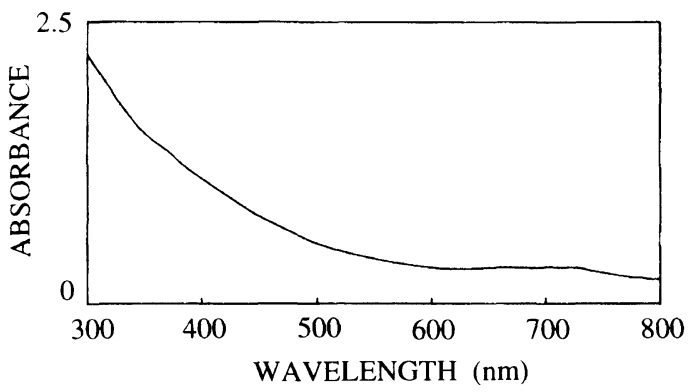

Figure 4. UV-Vis spectra of $\mathrm{Mg}(\mathrm{II})-\mathrm{taPc}$ film containing (a) $\mathrm{Mg}^{2+}$ and (b) $\mathrm{Ca}^{2+}$ as bridging metal ion.

metal ion are shown in Figure 4. The absorbance of $\mathrm{Mg}(\mathrm{II})$-taPc film containing $\mathrm{Ca}^{2+}$ as bridging metal ion was about 12 times that of $\mathrm{Mg}(\mathrm{II})$-taPc film containing $\mathrm{Mg}^{2+}$ as bridging metal ion. The spectra show that these films especially take up light in the short wavelength region or high energy region.

The turn-on voltage of the diode based on $\mathrm{Mg}$ (II)-taPc film containing $\mathrm{Mg}^{2+}$ as bridging metal ion was high, while the breakdown voltage was very low (Figure 3). In the present devices in Table I, more than $0.8 \mathrm{~V}$ applied voltage was necessary for the generation of photoconduction under the forward biased condition. These results suggest that Mott-type barriers, which would prevent the rising of forward biased current because of a thin resistive layer, are formed at the interface of semiconductor and aluminum. ${ }^{17,20}$ It is thought that applying high voltage is necessary for charge carrier transfer at the interface of the $\mathrm{Mg}(\mathrm{II})$-taPc film containing bridging metal ions and aluminum electrode under the forward biased condition, while charge carriers are transferred by tunneling effect under the reverse biased condition.

It was confirmed by SEM observation that the film containing $\mathrm{Mg}^{2+}$ as bridging metal ion had a comparatively flat surface while the film containing $\mathrm{Ca}^{2+}$ as bridging metal ion and one containing $\mathrm{Zn}^{2+}$ as bridging metal ion had rough surfaces. The flatness of surface of film containing $\mathrm{Mg}^{2+}$ as bridging metal ion may promote effective tunneling of valence electrons at the junction between $\mathrm{Mg}(\mathrm{II})-\mathrm{taPc}$ film containing $\mathrm{Mg}^{2+}$ as bridging metal ion and aluminum electrode under the reverse biased condition, since it can be expected that the barrier layer is thin enough for the tunneling effect.

\section{CONCLUSION}

$\mathrm{Mg}$ (II)-taPc films containing bridging metal ions were obtained from DMF solutions containing $\mathrm{MgCl}_{2}, \mathrm{CaCl}_{2}$, $\mathrm{CoCl}_{2}$, or $\mathrm{ZnCl}_{2}$ as supporting electrolyte. The present devices based on these $\mathrm{Mg}$ (II)-taPc films have potentially 
useful features for Zener-type diodes or photoelectric tubes. In particular, the diode based on $\mathrm{Mg}(\mathrm{II})-\mathrm{taPc}$ film containing $\mathrm{Mg}^{2+}, \mathrm{Ca}^{2+}$, or $\mathrm{Zn}^{2+}$ as bridging metal ion exhibited reproducible electrical properties and photocurrent. The diode based on $\mathrm{Mg}$ (II)-taPc film containing $\mathrm{Mg}^{2+}$ as bridging metal ion exhibited a Zener-type breakdown on dark condition. This would be due to bridging metal ions in electrodeposited $\mathrm{Mg}(\mathrm{II})$-taPc film. The diode based on $\mathrm{Mg}(\mathrm{II})$-taPc film containing $\mathrm{Ca}^{2+}$ as bridging metal ion showed the largest photocurrent/ dark current. These results suggest that the bridging metal ion in the $\mathrm{Mg}(\mathrm{II})-\mathrm{taPc}$ film is an important factor for deposition of $\mathrm{Mg}(\mathrm{II})-\mathrm{taPc}$ film and the diode performance.

Acknowledgments. We are grateful to $\mathrm{Mr}$. T. Sakaguchi (Technical Research Laboratories, Ishihara Sangyo Co., Inc.) for help in the setting and operation of the electrometer and high vacuum evaporator and Dr. T. Yamazaki (Nagano Prefectural Institute of Technology) for kind help in the operation of the SEM machine.

\section{REFERENCES}

1. M. Tanaka and S. Koma, "Phthalocyanine," Bunshin-Shuppan, Tokyo, 1991.

2. D. Wöhrle and B. Schulte, Makromol. Chem., 189, 1167 (1988).

3. M. Wang, H. Z. Chen, and S. L. Yang, J. Photochem. Photobiol. A: Chem., 88, 183 (1995).

4. N. C. Khe and M. Aizawa, Nippon Kagaku Kaishi, 393 (1986).

5. C. W. Tang, Appl. Phys. Lett., 48, 183 (1986).
6. M. Hiramoto, Y. Kishigami, and M. Yokoyama, Chem. Lett., 119 (1990).

7. M. Hiramoto, H. Fujiwara, and M. Yokoyama, Appl. Phys. Lett., 58, 1062 (1991).

8. M. Hiramoto, H. Fujiwara, and M. Yokoyama, J. Appl. Phys., 72, 3781 (1992)

9. D. L. Morel, A. K. Ghosh, T. Feng, E. L. Stogryn, P. E. Purwin, R. F. Shaw, and C. Fishman, Appl. Phys. Lett., 32, 495 (1978).

10. R. O. Loutfy and J. H. Sharp, J. Chem. Phys., 71, 1211 (1979).

11. M. Tomida, S. Kusabayashi, and M. Yokoyama, Chem. Lett., 1305 (1984).

12. M. Matsumura, H. Uohashi, M. Furusawa, N. Yamamoto, and H. Tsubomura, Bull. Chem. Soc. Jpn., 48, 1965 (1975).

13. Y. Shirota, T. Kakuta, H. Kanega, and H. Mikawa, J. Chem. Soc., Chem. Commun., 1201 (1985).

14. T. Fukuzawa, T. Koyama, G. Schneider, K. Hanabusa, and H. Shirai, J. Inorg. Organomet. Polym., 4, 261 (1994).

15. A. Kunioka and K. Kamimura, "Kiso-Handotai-Kogaku," Asakura-Shoten, Tokyo, 1992.

16. K. Misoh, S. Tasaka, S. Miyata, and A. Yamada, Kobunshi Ronbunshu, 41, 183 (1984).

17. M. Aoki, “Ohyo-Bussei-Ron," Asakura-Shoten, Tokyo, 1969.

18. F. H. Moser and A. L. Thomas, "The Phthalocyanine," CRC Press, Boca Raton, Florida, 1983.

19. M. Onoda, J. Appl. Phys., 78, 1327 (1995).

20. W. Bantikassegn and O. Inganäs, J. Phys. D: Appl. Phys., 29, 2971 (1996).

21. H. Shirai, A. Maruyama, K. Kobayashi, and N. Hojo, Makromol. Chem., 181, 575 (1980).

22. J. D. Lee, "Concise Inorganic Chemistry," D. Van Nostrand, London, 1965.

23. J. E. Huheey, "Inorganic Chemistry," 3rd ed, Harper \& Row, New York, N.Y., 1983.

24. S. Kurihara, "Tunnel-Kohka," Maruzen, Tokyo, 1994.

25. K. Yoshino and M. Onoda, "Kobunshi-Electronics," CORONA, Tokyo, 1996. 